Manuela Ingaldi ${ }^{1}$, Marta Jagusiak-Kocik ${ }^{2}$

\title{
QUALITY ASSURANCE IN THE TECHNOLOGY PROCESS OF WATER TREATMENT
}

\begin{abstract}
The chapter presents basic information about drinking water. Briefly water treatment processes have been characterized. We analyzed the water company. One of the water intakes of water treatment by the method of biological denitrification and its disinfection by ozonation, the pump station and treatment plant located in the province of Silesia. Process of water treatment for human consumption depicted technologically was presented. The identification of the problem of failure of water supply based on Ishikawa diagram was made.
\end{abstract}

Key words: drinking water, water treatment processes, water supply, production process depicted technologically, Ishikawa diagram

\section{Introduction}

Since the early 90 's there has been a steady decline in water consumption in Poland as well as in the whole of Europe. It is caused, among other things:

- technological progress,

- rational use of water,

- increasingly higher prices of water,

- repairing leaky installation (KLUGIEWICZ J., PASELA R. 2005).

Studies show that most uses of water for flushing toilets, in second place is bathing in the bath or shower, then scouring. In last place are cleaning and cooking.

A man in his existence needs water, water that is drinkable. Drinking water is water, which is a foodstuff intended for human consumption as well as other beneficial uses that require specific conditions of hygiene. Used by human water needs to be: any water in its original state or after treatment, which is suitable for drinking, cooking, food preparation or other domestic

${ }^{1}$ dr inż., Czestochowa University of Technology, Faculty of Management, Institute of Production Engineering, e-mail: manuela@gazeta.pl

2 mgr inż., Czestochowa University of Technology, Faculty of Management, Institute of Production Engineering, e-mail: m.jagusiak-kocik@o2.pl 
uses, regardless of the origin (a network of water pipes, tanks, bottles or other containers). Drinking water is any water in its original state or the treatment intended for drinking, cooking, preparing food and drinks, or other domestic uses such as washing and personal care, cleaning items, designed in accordance with their intended use in contact with food, cleaning items designed in accordance with the their purpose is not just a momentary contact with the human body.

\section{Water treatment processes}

Water for human use must be clean, free of pathogens and suitable for consumption. This condition should be considered satisfied if the acquiring, treatment, and distribution of water are maintained generally accepted rules, techniques.

The raw water coming from clean sources, and does not require treatment, ie fulfilling all statutory conditions related to quality is the best alternative for water supply network. However, other raw water tend to be in a suitable condition requiring treatment. An example may be a source of water with dissolved calcite, ground water with reduced iron and manganese or surface water colloidal suspensions of organic and inorganic origin. These ships natural obstacles are overcome in the process of treatment (GIMBEL R., JEKEL M., LIEBFELD O. 2008).

Raw water status in developed countries had deteriorated. The reason for this state of affairs looks for in a highly developed industry, agriculture and changed human lifestyle. Now, in addition to the pollution of natural origin have also to deal with anthropogenic pollution, which also need to deal with. Pollutions can also be divided into inorganic and organic.

Knowing the chemical and physical composition of water, it can use the appropriate technique for its treatment. But the method of treatment also depends on the quality of the water they want to achieve. Most often removed from the water, or destroyed are:

- pollutants that cause turbidity and color,

- substances contributing to the formation of the taste and smell,

- natural and anthropogenic pollutions,

- compounds of heavy metals, iron and manganese, 
- nitrates,

- dissolved gases,

- bacteria, viruses, algae, parasites (KowAL A., ŚWIDERSKA-BRÓŻ M., 2009).

The processes that are used for water purification can be divided into biological, physical and chemical or mixed. The processes which are used for water treatment are:

- aeration (removing of dissolved gases that cause the taste and smell, removing of volatile organic compounds and carbon dioxide, and also increasing the oxygen content. Increased oxygen causes oxidation of iron and manganese and prevents problems with taste and smell of water) (GIMBEL R., JEKEL M., LIEBFELD O., 2008),

- coagulation (removing from water particles about the colloidal comminution joined to oneself into larger aggregates about with irregular structure. But also in the process of coagulation are removed: fine suspensions resulting color and turbidity, bacteria, polycyclic aromatic hydrocarbons, heavy metals and pesticides),

- sedimentation and flotation (sedimentation is the process of sinking particles in water. During the sedimentation pollutants are being removed about the high density than water. This process depends on the properties, i.e. density, shape, size, temperature, flow direction, speed and suspension concentration. During flotation of the separation of the solid phase and a liquid phase. Flotation is used alternatively instead of sedimentation if the solid particles are less than, or not much differing from the density of water),

- filtration (purification by water flow through the filter beds. The top layer of the bed is fine-grained sand beneath him find a coarse sand and gravel. An important role during the filtration process plays a biological film, which takes the smallest of the suspension and micro-organisms),

- ion exchange (removing of solutes. Essence of ion exchange is to change the busiest ions to ions of the same character occurring in the ion exchange resin. Exchange of cations allow cations and anions - anions) (KowAL A., ŚwIDERSKA-BRÓż M., 2009),

- sorption (removing of organic compounds dissolved in the water. Activated carbon materials on which the effect of reducing the 
phenomenon of the sorption of the impurity content contributing to the formation of color, smell and taste of water) (NAWROCKI J.,2010),

- chemical oxidation (removes compounds that cause the taste, smell and color, oxidizes refractive compounds, converts the biodegradable substances are not biodegradable, promotes flocculation, oxidizes iron and manganese, disinfects. The used oxidizing agents are: ozone, chlorine dioxide, potassium permanganate, hydrogen peroxide, chlorine) (NAWROCKI J.,2010),

- membrane processes (separation of impurities at the stage or molecular ion. Processes are new, rapidly growing, were mainly used in the desalination of brackish water, sea water, sometimes softening and removal of the heavy metals, radionuclides, organic matter, nitrate ions. For membrane processes include: nanofiltration, reverse osmosis, reverse electrolysis, electrolysis, microfiltration and ultrafiltration) (BODZEK M., KONIECZNY K. 2011),

- biological processes (occurring in many water purification schemes, including the: infiltration, slow filtration, a biologically active fields, in reactors for biological nitrification and denitrification).

\section{Characteristics of the company}

The subject of research is the waterworks company. The company's headquarters is located: Department of Maintenance of mechanical and electrical workshops, Faculty of Transport and Equipment, Central Laboratory of Water and Wastewater, and warehouses. In contrast, technological facilities are located in different places.

The company also oversees the objects that do not have a fixed service, they are: water treatment plants, sewage pumping stations, water pumping stations, water tanks. Such facilities are more than 100, and they are constantly monitored.

One of the water intakes of water treatment by the method of biological denitrification and its disinfection by ozonation, the pump station and treatment is situated in the Silesia voivodeship. Nitrates removal station was built for removing of nitrate from surface water abstracted by wells. 
Station is designed to treat part of abstracted water so that the water mixed produced for the city of nitrate content does not exceed $50 \mathrm{mg} / \mathrm{l}$, i.e. normative value.

\section{Process of water treatment for human consumption depicted technologically}

The structure of the production process depicted technologically is defined as the operation phases and interfaces along with the technology in materials, energy and information necessary to produce the final product (DURLIK I. 1998).

The process of biological treatment of water by denitrification on the basis of the analyzed station depicted technologically was presented in the Figure 1.

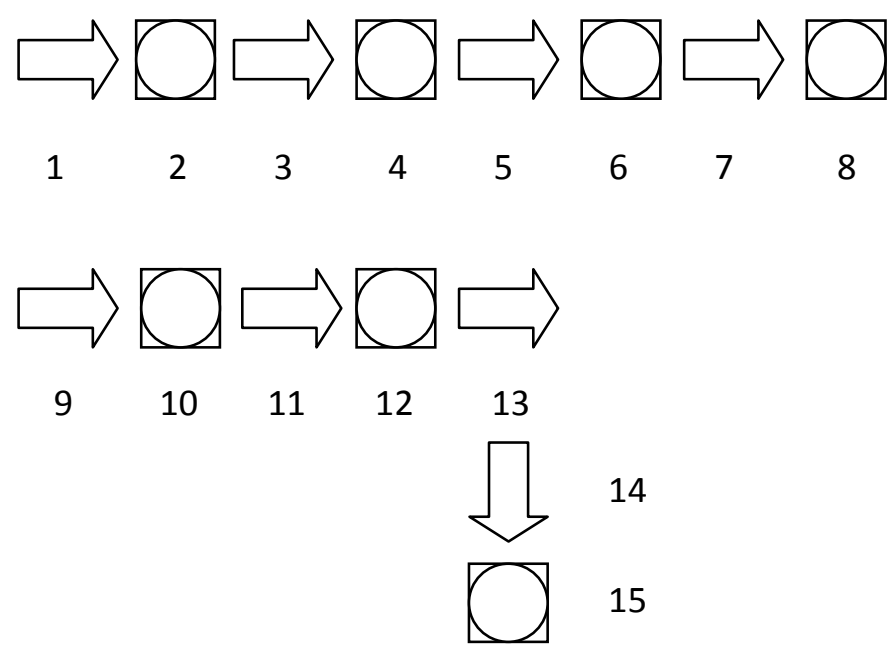

Fig. 1. The scheme of water treatment process using method of biological denitrification depicted technologically.

Source: own study 
Characteristics of the individual steps of the production process (Borkowski S., Ulewicz R. 2008, DuRliK I.1998, BurChaRT-KorOL D., FURMAN J. 2007):

1. Raw water supply.

2. Dosage cultures: phosphoric acid and ethanol combined with the control.

3. Water transport to biofilters.

4. Biological denitrification in bioreactors combined with the control.

5. Water transport to aerator.

6. Aeration and water flocculation in the aerator combined with the control.

7. Water transport to the filter with 2 media mother lode.

8. Water filtration on a 2 media mother lode and water control.

9. Water transport to activated carbon filters.

10. Water filtration on activated carbon and water control.

11. Water transport to into the ozone.

12. Water disinfection with ozone and final inspection of treatment water.

13. Discharge of water to the water supply.

14. Wash water transport to the settlers.

15. Industrial treatment of sludge and control.

\section{Identification of the problem of water supply failure based on Ishikawa Diagram}

Ishikawa diagram (BORKOWSKI S. 2004., BORKOWSKI S. 2012., KONSTANCIAK M., JAGUSIAK-KOCIK M. 2012, HAMROL A. 1998, INGALDI M., ROSAK-SZYROCKA J., JAGUSIAK-KOCIK M. 2012) is also known as a fish bone diagram or cause and effect diagram. It belongs to the traditional tools of quality management. Thanks to the Ishikawa diagram, you can determine the cause of nonconformities that occur in the enterprise and the relationships between these causes. As a result, it becomes easier to locate error, and after taking appropriate measures to eliminate it, as well as a reduced risk of recurrence.

Ishikawa diagram is used to:

- illustrate the complexity of the situation,

- record ideas,

- find relationships between different causes, 
- find the source of the problem,

- analysis of the results,

- highlight the essence of the relationship between the causes,

- a plan issues.

Cause and Effect Diagram is used in the production process as a means of finding the reasons that cause problems, as well as a document reminiscent of those reasons. Thanks to the staff remember the continuous monitoring of locations where there may be problems of quality.

Leaks in water supply networks is one of the causes of the accident. Failures are inevitable, but can be reduced in a manner consistent and methodical. To the effects of leaks:

- loss of water as a product for sale,

- contamination of tap water,

- collapse of terrain,

- prevent pedestrian and vehicular,

- ingress of water into objects,

- washes out the foundations of nearby buildings (BERGER M., WAYS M., 2003).

Causes of failure of the water supply system using the Ishikawa diagram are shown in Figure 2.

In most Polish cities conducted a study on the failure of water supply. While distributing the water reaches up to $10-15 \%$ of the daily loss of water production. An important element is the pipeline diagnostics includes an assessment of the technical condition, the test failures and detecting their causes. The study is subject to water quality, hydraulic performance and endurance. Diagnosis of water supply is not always clear, due to the fact that we are dealing with underground infrastructure. Pipeline control include a visual examination of the surface of the water outflow and observations of changes in pressure in the pipes.

Failures occur during normal operation and are random. Any material from which the pipes are made has a certain time of operation. What pipes are older and no longer in operation, the worse the condition of pipelines and frequent damage. Companies can reduce the number of failures by adopting the appropriate strategy:

- emergency - when failures are frequent, 
- periodic replacement - replacement parts pipelines according to the manufacturer's instructions,

- based on the results of inspections,

- forecasting - taking into account the results of the inspection (DOHNALIK P. 2000).

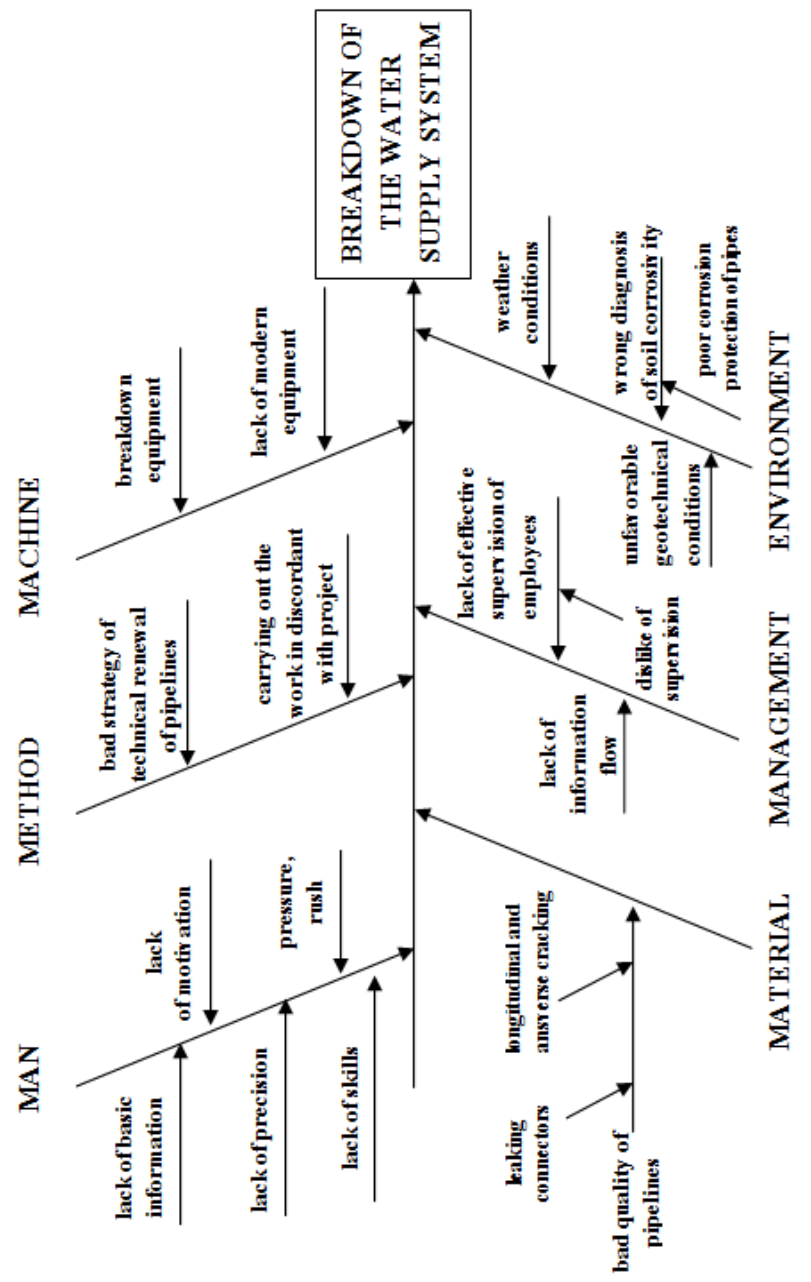

Fig. 2. Ishikawa diagram for breakdown of the water supply system.

Source: own study 
In order to repair a failure of pipelines used for the new exchange, and trenchless renovation of the pipeline network. We can distinguish several methods of restoration:

- covering mortar,

- method of crushing,

- method sleeve

- method of introducing plastic pipes (DOHNALIK P., JĘDRZEJEWSKI Z. 2004).

Long-term strategy allows for precise determination of time of replacement or renovation of the water supply network. This improves quality and reduces the risk of selection of unforeseen failure. Thorough analysis and the possibility of predicting failure should be the goal of the strategy of the company.

\section{References}

1. Berger M., Ways M. 2003. Poszukiwanie przecieków sieci wodociagowych Poradnik. Wydawnictwo „Seidel-Przywecki” Sp. z o.o. Warszawa.

2. BODZEK M., KONIECZNY K. 2011. Usuwanie zanieczyszczeń nieorganicznych ze środowiska wodnego metodami membranowymi. Wydawnictwo SeidelPrzywecki. Piaseczno.

3. BoRKowski S. 2004. Mierzenie Poziomu Jakości. Publisher WSZiM, Sosnowiec.

4. BORKOWSKI S. 2012. Tradycyjne narzędzia zarządzania jakościa. Teoria i praktyka. Ofic.Wydaw.Stowarzyszenie Menedżerów Jakości i Produkcji (SMJiP). Częstochowa.

5. BoRKOWsKi S., UlewICZ R. 2008. Zarządzanie produkcja. Systemy produkcyjne. Oficyna Wydawnicza „Humanitas”. Sosnowiec.

6. BURCHART-Korol D., FURMAN J. 2007. Zarzadzanie produkcja i ustugami. Wydawnictwo Politechniki Śląskiej. Gliwice.

7. DOHNALIK P. 2000. Straty wody $w$ miejskich sieciach wodociagowych. Wydawnictwo Polskiej Fundacji Ochrony Zasobów Wodnych. Bydgoszcz.

8. DOHNALIK P., JĘDRZEJEWSKI Z. 2004. Efektywna eksploatacja wodociagów, ograniczenie strat wody. Wydawnictwo Lemtech. Kraków.

9. DURLIK I. 1998. Inżynieria zarządzania. Strategia i projektowanie systemów produkcyjnych Czesść I. Wydawnictwo PLACET. Warszawa. 
10. Gimbel R., JeKel M., Liebfeld O. 2008. Podstawy i technologie uzdatniania wody. Wydawnictwo PROJPRZEM-EKO. Bydgoszcz.

11. HAMrol A. 2008. Zarządzanie jakościa $z$ przykładami, wydanie 2. Wydawnictwo PWN. Warszawa.

12. IngAldi M., RoSAK-SzYROCKA J., JAGUSIAK-KocIK M. 2012. Service Quality in the Point of the Mass Nutrition. Chapter 1. W: Toyotarity. Quality of Services Assessment According to BOST Method. Monography. Editing and Scientific Elaboration BORKOWSKI S., INGALDI M. Faculty of Logistics, University of Maribor. Celje.

13. KonstanciaK M., JagusiaK-KociK M. 2012. Quality Control in the Company Processing the Metallurgical Wastes. Chapter 5. W: Quality of Materials. Monography. Editing and Scientific Elaboration BORKOWSKI S., KLIMECKATATAR D. Oficyna Wydawnicza Stowarzyszenia Menedżerów Jakości i Produkcji. Częstochowa.

14. KlugiewiCz J., PASElA R. 2005. Gaz, woda i technika sanitarna. Wydawnictwo Czasopism i Książek Technicznych SIGMA -NOT Sp. z o.o. Warszawa. Nr1.

15. Kowal A., ŚwidersKA-Bróż M., 2009. Oczyszczanie wody. Podstawy teoretyczne

$i$ technologiczne, procesy $i$ urzadzenia. Wydawnictwo Naukowe PWN. Warszawa.

16. NAwrocki J. 2010. Uzdatnianie wody. Część I. Wydawnictwo Naukowe PWN. Warszawa. 